\title{
H2BC17 wt Allele
}

National Cancer Institute

\section{Source}

National Cancer Institute. H2BC17 wt Allele. NCI Thesaurus. Code C162960.

Human $\mathrm{H} 2 \mathrm{BC} 17$ wild-type allele is located in the vicinity of $6 \mathrm{p} 22.1$ and is approximately 1 $\mathrm{kb}$ in length. This allele, which encodes histone H2B type 1-O protein, is involved in the regulation of DNA accessibility. 